\title{
1Strain localisation and grain breakage in sand under shearing 2at high mean stress: insights from in-situ x-ray tomography
}

\author{
3Alikarami R. ${ }^{1,2}$, Andò, E. ${ }^{3}$, Gkiousas-Kapnisis M. ${ }^{3}$, Torabi A. ${ }^{1}$, Viggiani G. ${ }^{3}$ \\ $4^{1}$ Uni CIPR, Uni Research , P.O. Box 7810, N-5020 Bergen, Norway \\ $5^{2}$ Earth Science Departments, University of Bergen, P.O. Box 7800, N-5020 Bergen, Norway \\ $6^{3}$ Grenoble-INP / UJF-Grenoble 1 / CNRS UMR 5521, Laboratoire 3SR, 38041 Grenoble, France \\ 7Corresponding author: Reza Alikarami, Uni CIPR, Uni Research , P.O. Box 7810, N-5020 Bergen, Norway \\ 8(reza.alikarami@uni.no)
}

9

\section{Abstract}

11 This work presents results from a series of triaxial compression tests on two quartz sands 12(differing principally in grain shape), at confining pressures high enough to cause grain breakage 13during shearing. Tests are performed inside an x-ray scanner, which allows specimens to be 14imaged non-destructively as they deform. Observation of the acquired images clearly shows 15different mechanisms of deformation, including shearing, dilation, compaction and grain 16breakage. These mechanisms are investigated quantitatively through 3D measurements of local 17porosity, as well as strain (obtained by 3D Digital Image Correlation), which is analysed in terms 18of volumetric and shear components. These tools allow the transition between macroscopically 19dilative (typically of a dense sand at low mean stress) and compactive behaviour to be 20investigated. The analysis reveals that at the high end of the confining pressure range studied 21(100 to $7000 \mathrm{kPa}$ ) the more rounded sand deforms with highly localised shear and volumetric 22strain - the porosity fields show a dilative band within which a compactive region (due to grain 23crushing) grows. The more angular material shows shear strain localisation, however its faster 24transition to compactive behaviour (due to a higher propensity for individual grains to crush) 25translates to much more distributed compactive volumetric strain.

\section{Keywords}

27Deformation band, Grain breakage, Grain shape (angularity), Triaxial compression test, In-situ x28ray microtomography, 3D Digital Image Correlation 


\section{Introduction}

31 Weakly cemented and poorly lithified sandstones are important class of geological reservoirs 32for hydrocarbon production and are good candidates for geological carbon dioxide sequestration 33due to their high porosity and permeability. These highly porous rocks undergo different modes 34of deformation depending on their stress history as well as their lithological and petrophysical 35properties. Strain in such sandstones may localise into thin (mm-scale) planar structures often 36referred to as deformation bands [1-3]. The kinematics of deformation bands always includes 37shear, while the volumetric response ranges from dilative to compactive strain (e.g. [1, 4]). Both 38porosity and permeability are reduced within compaction bands and compactive shear bands, as a 39result of pore-collapse and possible grain breakage [5-7]. In dilative shear bands, porosity 40increases and (depending on pore tortuosity and changes in specific surface area) permeability 41may decrease or increase [8-10]. Extensive experimental work has been carried out to study the 42effects of variables such as stress level, porosity and grain size on localised deformation in well 43lithified and cemented sandstone (e.g. [11-15]).

44 At the micro-scale (i.e. the scale of the grain, for a sandstone), strain corresponds to 45combinations of different mechanisms including grains rearrangement (sometimes referred to as 46“particulate flow”), grain breakage (cataclasis) and cement breakage. A full understanding of 47strain localisation in sandstones requires investigation of these mechanisms, all of which strongly 48depend on grain shape and angularity. Experience and knowledge from our previous work on 49natural compactive shear bands formed in very porous and friable sandstone (e.g., [16, 17]) were 50the motivation to explore the behaviour of sand at high mean stress. In this paper, sand is adopted 51as a model material that allows the investigation (at substantially lower mean stresses than that 
52needed for sandstone) of all deformation mechanisms mentioned above at the grain scale - with 53the exception of cement breakage.

54 X-ray tomography is proving to be an ideal tool for the investigation of the micro55mechanisms of deformation in sand - for example recent work from Laboratoire 3SR, Grenoble, 56has clearly demonstrated the effect of grain angularity on the macroscopic mechanical behaviour 57of sand as well its effect on the formation and development of shear bands in different types of 58sand [18-20], all this at relatively low mean stress, which rules out grain breakage.

59 A series of dry triaxial compression tests on two different sands has been performed in-situ 60(i.e. performing $\mathrm{x}$-ray scans at various points throughout loading) inside the $\mathrm{x}$-ray scanner in 61Laboratoire 3SR (Grenoble), at mean stresses up to $7000 \mathrm{kPa}$ - which proves to be high enough 62to cause grain breakage. The two sands tested are both quartz sands, with similar grain size 63distributions but different angularities: Ottawa 50-70 sand (rounded) and Hostun HN31 sand 64(angular).

65 The structure of the paper is as follows: the materials and testing method are first described; 66this is followed by a description of the tests performed. The typical, macroscopic measurements 67obtained from triaxial testing are detailed for all tests. The image processing tools used to make 68micro-scale measurements on the acquired $\mathrm{x}$-ray images are then briefly described. These 69measurements are further used to explain the differences in the macroscopic responses observed. 70The paper closes with a discussion of the results obtained. 


\section{Experiments}

\subsection{Materials tested}

73 The two different types of sand tested in this work are Hostun HN31 sand and Ottawa 50-70 74sand. Hostun sand is angular siliceous sand (see SEM image in Fig. 1) produced in a quarry close 75to the commune of Hostun in the Rhône-Alpes region of France. The Hostun HN31 sand studied 76in this work [21] is mechanically identical to the "Hostun S28" and "Hostun RF" varieties that 77have been thoroughly studied (e.g. [22]). The Ottawa sand is a rounded siliceous sand (see SEM 78image in Fig. 1), that comes from sedimentary deposits in Ottawa, Illinois (U.S.A.). A particle 79size distribution for both sands is presented in Fig. 2; the values of $\mathrm{D}_{50}$ of Hostun and Ottawa 80sands are $338 \mu \mathrm{m}$ and $310 \mu \mathrm{m}$, respectively.

\subsection{Experimental setup and testing campaign}

82 A series of triaxial tests on small specimens of dry Hostun and Ottawa sands at confining 83pressures ranging from $100 \mathrm{kPa}$ to $7000 \mathrm{kPa}$ have been carried out at Laboratoire 3SR with in84situ x-ray scanning. The specimens used in this work are cylinders of approximately $22 \mathrm{~mm}$ 85height and $11 \mathrm{~mm}$ diameter, with non-lubricated end platens. Note that from a mechanical 86standpoint, the response obtained with such small specimens compares well to that obtained with 87larger (standard size) specimens (in [23]), as discussed in detail in [24].

88 The triaxial cell has no steel tie-bars to take the return force from the axial compression of 89the specimen; this is instead taken by the cell in tension (see Fig. 3). The absence of steel tie-bars 90allows the specimen to be imaged by x-rays, without disturbance, inside the cell. Two triaxial 91cells were used in this experimental campaign: a high and a low pressure cell, which differ 92principally in the thickness of the wall of the cell, as well as how the confining pressure is 93applied. Both cells are made of PMMA (Plexiglas) which is transparent to visible light as well as 
94to x-rays. In the lower pressure cell shown in Fig. 3 (designed for confinements up to $1000 \mathrm{kPa}$ ), 95the confining fluid is water, and confining pressure is applied by compressed air (coming from a 96compressor) with a pressure controller, allowing a fine control of the confining pressure. For the 97higher pressure cell, confinement by air is no longer feasible, and so a pump is used; for 98compatibility with the pump, the confining fluid is oil.

99 Given the different confining pressures and fluids, two different membranes have been used 100in this experimental campaign. In the lower pressure tests, a $300 \mu \mathrm{m}$ thick latex membrane (very 101transparent to x-rays) is used. In the higher pressure tests, however, a $500 \mu \mathrm{m}$ thick neoprene 102membrane is used - primarily to avoid piercing of the membrane, but also for compatibility with 103the confining fluid. The x-ray absorption of this membrane is considerably higher than the latex 104one, so it is clearly visible in the images coming from x-ray tomography (see Fig. 6).

105 All specimens are prepared by air pluviation into the membrane stretched in a mould, aiming 106for a dense initial packing (this specimen preparation technique has been selected for its 107reproducibility). Once prepared, samples are installed into the triaxial cell with vacuum applied to 108the sample. The cell is then filled with the relevant confining fluid, which is slowly pressurised to 109an initial isotropic state, while the vacuum is released.

110 Each specimen is loaded isotropically until the desired confining pressure is reached, at 111which point deviatoric loading is applied under strain control by shortening the sample axially 112using a domed ram driven up by the loading system. The force required to advance the ram is 113recorded with a load cell, and the displacement of the ram is recorded with an LVDT. The 114specimen is shortened with a displacement rate of $21 \mu \mathrm{m}$ per minute (corresponding to a nominal 115 strain rate of just under $0.1 \%$ per minute). 
116 At various key points during a test, loading is halted, and a tomographic scan is performed 117by acquiring 1024 x-ray radiographs of the sample as it is rotated $360^{\circ}$ around its vertical axis by 118the rotation stage visible in Fig. 3. Since the specimens scanned are relatively small, the 119geometrical zoom provided by the x-ray cone-beam coming from the generator gives a pixel size 120of $15.6 \mu \mathrm{m} /$ pixel, meaning that each grain within the specimen (we recall the $\mathrm{D}_{50}$ is bigger than $121300 \mu \mathrm{m}$ for both sands) is clearly represented. The set of radiographs acquired is then 122reconstructed (using DigiCT 2.4.2 from Digisens) into a 3D field of the x-ray attenuation inside 123the specimen.

\section{Macroscopic results of triaxial testing}

125 This section presents the macroscopic results coming from the triaxial compression tests 126analysed in this work (see Table 1).

127Table 1. Summary of tests analysed in this paper

\begin{tabular}{cccc}
\hline Material & $\begin{array}{c}\text { Test } \\
\text { Name }\end{array}$ & $\begin{array}{c}\text { Confining } \\
\text { Pressure }\end{array}$ & $\begin{array}{c}\text { Initial Porosity } \\
\text { (before shearing) }\end{array}$ \\
\hline Ottawa & OUEA06 & $100 \mathrm{kPa}$ & $32.1 \%$ \\
Ottawa & OHEA03 & $4000 \mathrm{kPa}$ & $29.1 \%$ \\
Ottawa & OHEA01 & $7000 \mathrm{kPa}$ & $27.3 \%$ \\
Ottawa & OHEA02 & $7000 \mathrm{kPa}$ & $28.9 \%$ \\
\hline Hostun & HNEA01 & $100 \mathrm{kPa}$ & $37.7 \%$ \\
Hostun & HHEA03 & $1000 \mathrm{kPa}$ & $33.7 \%$ \\
Hostun & HHEA05 & $1000 \mathrm{kPa}$ & $34.8 \%$ \\
Hostun & HHEA04 & $2000 \mathrm{kPa}$ & $35.1 \%$ \\
Hostun & HHEA06 & $3000 \mathrm{kPa}$ & $34.3 \%$ \\
Hostun & HHEA02 & $4000 \mathrm{kPa}$ & $34.6 \%$ \\
Hostun & HHEA01 & $7000 \mathrm{kPa}$ & $33.8 \%$ \\
\hline
\end{tabular}

128 In some tests, a few scans are performed during the isotropic loading of the specimen, 129however most are during deviatoric loading. When deviatoric loading is halted to perform a scan, 130some axial stress relaxation occurs, which can be seen as small drops of deviator stress 
131throughout the $\mathrm{q} / \mathrm{p}$ vs. $\varepsilon_{\mathrm{a}}$ responses of both sands (see Figs. 4 and 5 noting that $p=\frac{1}{3}\left(\sigma_{a}+2 \sigma_{r}\right)$ 132and ${ }^{q=\left(\sigma_{a}-\sigma_{r}\right)}$ with $\sigma_{\mathrm{a}}$ and $\sigma_{\mathrm{r}}$ being the axial and radial stresses respectively).

133 Figures 4 and 5 show the deviator stress response normalised by the mean normal stress (q/p) 134and volumetric strain response (in \%) both against axial shortening (normalised by the initial 135height) for all the tests on Ottawa and Hostun sands. Since samples are tested dry, the 136macroscopic measurement of bulk specimen volume that is used to measure volumetric strain is 137actually derived from the images of the specimen - the technique for making this measurement is 138detailed in Section 4.1.

139 It is clear from the responses shown for both sands that there is a significant, but progressive 140change between the macroscopic material response at $100 \mathrm{kPa}$ and $7000 \mathrm{kPa}$ confinements. The 141triaxial compression behaviour of Ottawa sand (shown in Fig. 4) with increasing mean stress 142reveals a progressive retardation (with respect to axial shortening) of the peak deviatoric stress as 143well as a progressive reduction of its value. The difference between the peak deviator stress and 144the plateau is large at low confinement (test OUEA06), and the difference reduces with 145increasing confining pressure - as does the normalised $q / p$ value of the plateau. The considerable 146dilation undergone by the specimen at $100 \mathrm{kPa}$ confinement progressively reduces from 4000 to $1477000 \mathrm{kPa}$. Although the volumetric strain curves obtained for the two tests performed at $7000 \mathrm{kPa}$ 148confinement differ, the response can be seen to be slightly dilatant (compared to test OUEA06 at $149100 \mathrm{kPa}$ ) in both cases. 
150 The evolution of the mechanical response of Hostun sand (Fig. 5) with increasing confining 151pressure has the same sort of evolution as with the Ottawa sand described above (less clear peak 152stress and increasingly less dilatant behaviour), however, over the same range of confining 153pressures this evolution appears to be considerably more rapid: a peak in deviator stress is only 154clearly visible until $3000 \mathrm{kPa}$ confinement - at higher confinement there is no peak, only strain 155hardening. The volumetric response also displays a good deal more change than for Ottawa sand: 156the specimen tested at $100 \mathrm{kPa}$ confinement shows clear dilatancy, whereas the one tested at 7000 $157 \mathrm{kPa}$ confinement is contractant throughout. The other tests at 1000, 2000, 3000 and $4000 \mathrm{kPa}$ fall 158in between these two cases. The stress response of HHEA05 (1000 kPa confinement) also reveals 159a clear peak, yet with a lower dilatancy than HNEA01 at $100 \mathrm{kPa}$ confinement. Stress-strain 160responses of HHEA04 at $2000 \mathrm{kPa}$ and HHEA06 at $3000 \mathrm{kPa}$ confinement also show peaks but 161not as clearly marked as for HNEA01 and HHEA05. Their volumetric responses are very slightly 162dilatant in the case of HHEA04, and slightly contractant for HHEA06. Stress-strain response of 163sample HHEA02 tested at $4000 \mathrm{kPa}$ confinement reveals no peak, and shows contraction, but to a 164lesser extent than test HHEA01 at $7000 \mathrm{kPa}$.

165 During the post-test removal of specimens tested at high pressures, the production of fines 166was noted when the contents of the membrane was emptied for weighing. The production of fines 167by grain breakage may well explain the change from dilation to compaction in the macro-scale 168volumetric responses of these sands (see Figs. 4 and 5).

\section{Image analysis}

170 This section briefly outlines the image analysis techniques used to make micro-scale 171 measurements on the various 3D images coming from the tomographic scans during loading. The 172objective is to use these tools to explain the differences in the macroscopic responses detailed 
173above. The 3D images coming from tomography are 16-bit greyscale measuring 1741250x1250x1600 pixels, with a pixel size of $15.6 \mu \mathrm{m}$.

\subsection{Preparation of images for analysis}

176 In order to make micro-scale measurements from the acquired images, the first step is to 177define the domain (within the image) of the solid skeleton to be analysed, so that measurements 178are made only on this part of each image, and that other objects (such as the top and bottom 179platens, as well as the neoprene membranes) are not taken into account. The specimen-platen 180interface is considered to be a plane, which can be tilted with respect to the specimen's axis. 181Given that the platens have a long extent of flat greyscale (as opposed to the sample, which is 182made of grains and pores), this information is incorporated into an automatic procedure which 183automatically detects points on this interface and fits a plane to the two specimen-platen 184interfaces.

185 The shape of the membrane is rendered more complex by the fact that it does not necessarily 186have a uniform thickness (especially once the sample starts to undergo localised deformation); 187consequently, there is no question of manually removing the membrane, especially taking into 188account the large number of 3D images acquired. A specific image processing technique is 189therefore developed to recognise the inner surface of the membrane: for each horizontal slice, 300 190equally-spaced radial profiles are made, centred on the approximate axis of the specimen. As 191illustrated in Fig. 7, the plot of the variance of this profile reveals sharp peaks, corresponding to 192the rapidly changing greyscale values at material interfaces. Each greyscale profile is variance 193filtered and the characteristic peaks are used to identify the border points: a closed border 194defining the inside of the membrane is then created by connecting these 300 individual points by 195linear segments. Finally, a 3D median filter (of radius 5 pixels) is used to smooth out this border. 
196The full technique is shown in Fig. 7, and its effectiveness can be seen from the way in which the 197membrane visible in Fig. 6b is removed in Fig. 6c.

198 After each individual stage has been processed, the inside of the specimen is defined with a 199geometrically complex border around the inside of the membrane bounded by two planes. The 200number of voxels (3D pixels) within this space can be counted, using the pixel size, and used to 201calculate the bulk volume of the specimen as imaged.

\subsection{Local measurement of porosity}

203 Porosity is a key measurement for granular materials, and its spatial distribution is of 204particular interest given the different volumetric strain responses seen with macro-scale 205measurements. Porosity is defined as the ratio of the volume of voids to the total volume. This 206can be measured locally, by defining a 3D subvolume within a 3D image and measuring the 207volume of the voids within the subvolume. In previous work [26], voids have been counted by 208binarising the greyscale 3D image into a black and white image of the solid and void phases by 209applying a threshold. Observation of the images obtained in this work, particularly for Hostun 210sand at high confining pressure and after shearing shows that grain breakage does indeed occur 211(see Fig. 15 for example), and that the finer grains produced can be small compared to the pixel 212size of the images. This smaller grain phase partially fills voxels, and consequently looks like a 213homogeneous material of x-ray attenuation in between grain and void, thus invalidating the 214inherent two-phase hypothesis for binarisation. In this work, the volume of voids in each 215subvolume is calculated on the greyscale (as opposed to binary) 3D images; values of pore and 216grain greyscale are measured manually on a small selection of pores and grains throughout the

217specimen. Any voxel having a greyscale value equal to, or higher than, the grain greyscale value 218identified is $100 \%$ solid, and any voxel having a greyscale value equal to, or lower than, the pore 
219greyscale value identified is $100 \%$ pore. Greyscale values between these two greyscale limits are 220interpolated with a linear relationship.

221 Local measurements of porosity are therefore made by defining local subvolumes, centred on 222a number of regularly spaced nodes. The size of the cubic subvolumes is selected as a reasonable 223trade-off between sensitivity and representativity of the measurement. Subvolume sizes of 224620x620x620 $\mu \mathrm{m}$ and 470x470x470 $\mu \mathrm{m}$ are used to make measurements on Hostun and Ottawa 225sand respectively.

\subsection{Digital Image Correlation (DIC)}

227 In order to make measurements of local kinematics between two 3D images of a deforming 228specimen, Continuum Digital Image Correlation, as implemented in Tomowarp by Hall [27], has 229been used to follow regularly-distributed cubic subvolumes between two different greyscale 230images. The method relies on image correlation and attempts to find a pattern (i.e. the greyscale 231inside a given subvolume) extracted in the reference configuration, and looks for this pattern in 232the deformed configuration. When the best matching pattern is found (by optimizing a correlation 233coefficient mapping one image to the other), the displacement of the subvolume is a natural 234output, and is measured to subpixel precision. This gives the displacement of a series of points 235spread throughout the reference configuration, giving therefore, a full-field measurement of the 236kinematics between the two states. By deriving this displacement field, the 3D strain tensor can 237be obtained. The first two invariants of the strain tensor (representing volumetric and shear strain) 238are chosen for display in the results shown in Section 5.

239 Image correlation has an increased probability of making matching errors when a 240considerable amount of grain breakage occurs between steps. This is due to the considerably 
241different patterns from one image to another that naturally make the patterns harder to match. In 242order to minimize these potential errors, small increments are analyzed in this work. It is worth 243noting that DIC is used incrementally, i.e. to measure the displacement field from image i- 1 to 244image i, rather than from the initial configuration up to image i. This is different from the "total" 245porosity measurements presented in Section 5.

\section{Measurements from image analysis}

\subsection{Tests on Ottawa sand}

248 This section uses the 3D images acquired during the different tests on Ottawa sand to 249investigate the micro-mechanisms at play during triaxial shearing of the specimens tested at 100 , 2504000 and $7000 \mathrm{kPa}$ confining pressure.

251 Figure 8 shows vertical slices from the final states imaged in each test on Ottawa sand 252analysed in this work. The slices are oriented to contain the axis of the sample and the normal to 253the single shear band that is apparent in all cases. In all images acquired at high pressure, the 254membrane and platens have been removed using the technique described in Section 4.1. These 255images reveal that in OUEA06 a clear dilatant shear band crosses the sample, whereas for the two 256samples tested at $7000 \mathrm{kPa}$ confinement, a narrow compactive shear band is also visible, 257containing crushed material. OHEA03 is an intermediate case, i.e. with no change or slight 258change in porosity inside the shear band.

259 Figure 9 shows the porosity maps obtained for some key steps during the triaxial shearing of 260three of the specimens. Prior to shearing, all specimens have relatively uniform distribution of 261porosities ranging from $n=27 \%$ to $n=32 \%$. Specimen OUEA06 (tested at $100 \mathrm{kPa}$ confinement) 262presents a clear, dilatant shear band that develops early in the test - at 3.9\% axial shortening 
263(around the position of the peak stress) localised dilation is visible, with a porosity in the band of 264around $n=46 \%$ by the end of the test. OHEA03 (4000 kPa) does not seem to show localised 265changes in porosity at 3.9\% axial strain, however around its peak (at $7.7 \%$ shortening, which is 266considerably later than OUEA06), localised dilation is visible. This dilative band continues to 267develop with increasing shearing, and becomes more pronounced by the end of the test (reaching 268a value of $n=39 \%$ ). The sample tested at $7000 \mathrm{kPa}$ confinement (OHEA01) has a considerably 269different behaviour, which is captured well by looking at the porosity maps: by the end of the 270test, a band of reduced porosity is noticeable, reaching $n=33 \%$ ( $2 \%$ lower than the surrounding 271material). Looking back towards the beginning of the test, two mechanisms can be seen: there is a 272clear and relatively uniform densification of the sample between 0 and $4.3 \%$ shortening. 273Thereafter, a dilatant shear band is visible at $12.9 \%$ shortening (achieving a porosity of $n=36 \%$ ), 274and at $14.3 \%$ shortening, within this dilatant band, a zone of contraction starts to develop at the 275bottom of the band (on the right side of the specimen), and appears to progressively develop 276within the dilatant band as shearing continues: by $17.2 \%$ shortening it crosses the entire 277specimen. This contractive band is consistent in space with the zone of crushed material visible in 278Fig. 8.

279 Figure 10 shows the DIC results (vertical sections of the calculated fields of volumetric and 280shear strain) for some selected increments of the three tests analysed. Interestingly, incremental 281volumetric strain fields can reveal mechanisms that changes in total porosity simply are not 282sensitive enough to pick up. While over the peak the volumetric strain fields from DIC merely 283confirm the dilating bands shown by the porosity fields, the increments analysed at the end of the 284tests reveal that as shearing continues, the volumetric strain in the bands of localised shear strain 285either disappears (for the test at lowest confinement) or becomes compactive (in all the other 
286tests), likely due to grain breakage. The shear strain fields show that in all tests the shear band 287gets thinner after the peak.

\subsection{Tests on Hostun sand}

289 Figure 11 shows vertical slices from the final states imaged in each test on Hostun sand 290analysed in this work. The slices are oriented to contain the axis of the sample and the normal to 291the single shear band (when this is apparent).

292 As for Ottawa, in all images acquired at high pressure, the membrane and platens have been 293removed using the technique described in Section 4.1. These images reveal a range of final states 294that go from a high porosity band (at $100 \mathrm{kPa}$ and to a lesser extent at $1000 \mathrm{kPa}$ confinement) to a 295wide band with clear evidence of crushed grains (in the tests at 4000 and $7000 \mathrm{kPa}$ ). The tests at $2962000 \mathrm{kPa}$ and $3000 \mathrm{kPa}$ confinement are intermediate cases, with no striking changes in porosity 297throughout the specimen.

298 Figure 12 shows the porosity maps obtained for some key steps during the triaxial shearing 299of the specimens of Hostun sand. Prior to shearing, all specimens have relatively uniform 300distribution of porosities ranging from $n=27 \%$ to $n=32 \%$, with initial porosity generally 301decreasing with increasing confining pressure, as expected. Specimens HNEA01 and HHEA05 302both exhibit a clear shear band that becomes increasingly dilatant with increasing shortening 303with the out-of-band material remaining at almost constant porosity. Specimen HHEA04 tested at $3042000 \mathrm{kPa}$ confinement seems to deform with essentially no porosity change. A progressive and 305distributed reduction in porosity is evident in all specimens tested at higher cell pressure. 306Specimen HHEA02 shows some degree of localisation in porosity reduction at the end of the test. 
307 Figure 13 shows the DIC results (vertical sections of the calculated fields of volumetric and

308shear strain) for some selected increments of the three lower pressure tests. At $100 \mathrm{kPa}$ and 1000 $309 \mathrm{kPa}$ confinement, (shear and volumetric) strain localisation starts in a wide band and then 310progressively concentrates with increasing axial shortening. At $2000 \mathrm{kPa}$, the shear strain 311concentrates in a similar fashion, while the maps of incremental volumetric strain confirm that 312little or no volume changes occur during (progressively localised) shearing. The DIC results for 313the other three tests analysed (shown in Fig. 14) show that a shear band eventually forms in all 314tests - which was not evident from either x-ray images or the porosity maps. The reason for this 315can be seen in the volumetric strain increments presented, which show no localisation. It is also 316important to note that at these levels of confinement, volumetric strain is essentially compactive 317rather than dilative - consistent with the global volumetric strains shown in Fig. 5.

\section{Discussion and conclusions}

319 The range of cell pressures used in this experimental campaign has resulted in a significant 320evolution of the mechanical response of both tested sands, at the macroscopic level. The 321tendency for increasing confinement is for the volumetric response to change from dilative to 322contractive, and for the peak of the deviator stress to become less pronounced. This is entirely 323consistent with previous experimental findings (e.g. [28-30]), all of which attribute this change in 324macroscopic behaviour to the appearance of grain crushing with increasing mean stress - which 325is supported by post-mortem sieve analyses.

326 Grain crushing is generally studied through its numerous effects at the macro scale (e.g. its 327effect on compressibility, shear strength, permeability, etc.). In this work, the process of grain 328crushing is approached experimentally at the scale of the grain. X-ray micro tomography allows 329imaging of this process, which is a major mechanism of inelastic deformation in sand at high 
330pressure - along with granular rearrangement. Furthermore, the comparison of successive pairs of 331x-ray images (with 3D DIC) yields 3D (incremental) strain fields, which reveal the nature of the 332strain occurring between the two states.

333 In all the tests performed on Ottawa sand, shear strain and volumetric strain are observed to 334localise into a band a few grains thick. At high pressure, grain crushing only occurs in the shear 335band when a sufficiently high porosity is reached. It should be mentioned that this evolution is 336well portrayed by the first three stages (dilation, pore collapse and grain size reduction) in the 337sequence suggested by Lothe et al. [30] to describe the evolution of deformation bands in 338sandstones.

339 DIC measurements in Hostun sand show that while shear strains localise in a shear band at 340all pressures, volumetric strain is localised when dilatant (at low pressures) and becomes 341increasing less localised in the contractive regime. X-ray images show diffuse breakage at high 342pressure, with the relatively wide regions of porosity reduction corresponding in space to regions 343of crushed grains (see Fig. 15).

344 Since both Ottawa and Hostun are quartz sands with similar grain size distribution, the cause 345of their different responses can be mainly ascribed to the shape of their grains (rounded in the 346former and angular in the latter). One may hypothesise that in the more angular material the 347amount of energy required to break a grain is lower due to the presence of sharper contacts that 348concentrate stresses on the grain. Therefore, for a given stress level one would expect more 349crushing in the angular material - which is exactly what is observed. The massive grain crushing 350observed in Hostun sand at $7000 \mathrm{kPa}$ confinement suggests that the material is close to the stress 351conditions required for distributed grain breakage. In Ottawa sand, even at $7000 \mathrm{kPa}$ confinement 
352breakage only occurs after a strong reduction of porosity, which for a given stress increases 353interparticle forces - this happens only inside the narrow compactive shear band of localised 354strain (see Fig. 15). These differences manifest themselves in the macroscopic response of the 355two sands, most evidently in their volumetric response - with the specimens of Ottawa sand 356never showing overall compaction whereas Hostun crosses this threshold between 2000 and 3000 $357 \mathrm{kPa}$ confinement.

358 The findings of this study on sand highlight the central role played by grain shape on both 359the stress level needed to break grains as well as the patterns of deformation (localised vs. 360diffuse). It is the authors' contention that these findings are also largely applicable to poorly 361lithified sandstones. These results are of particular interest for hydrocarbon production and $\mathrm{CO}_{2}$ 362storage in sandstone, where the overall reservoir permeability and its evolution is key for the rate 363at which extraction/injection processes can occur. In the triaxial compression tests analysed in 364this work, similar materials differing only by the shape of their grains exhibited very different 365distributions of particle breakage, diffuse in the angular material and highly localised in the 366rounded one - with obvious implications for the permeability and its directional variation. The 367stress paths encountered in a natural reservoir are clearly quite different from triaxial 368compression, however one might expect grain shape to play an equally important role under any 369deviatoric stress path, such as those induced by oil production or $\mathrm{CO}_{2}$ injection.

\section{Acknowledgments}

371 This study is part of the IMPACT Project, a consortium R\&D project 207806, at the Centre 372for Integrated Petroleum Research (Uni CIPR), Uni Research, funded by the Research Council of 373Norway and Statoil. The authors would like to thank Alessandro Tengattini for his help in the 374quantitative analysis and interpretation of the test results. 


\section{References}

3761. Schultz RA, Siddharthan R (2005) A general framework for the occurrence and faulting of 377deformation bands in porous granular rocks. Tectonophysics, 411:1-18. doi: 37810.1016/j.tecto.2005.07.008

3792. Fossen H, Schultz RA, Shipton ZK, Mair K (2007), Deformation bands in sandstone: A 380review. J Geol Soc 164:755-769. doi: 10.1144/0016-76492006-036

3813. Torabi A, Berg S (2011) Scaling of fault attributes: A review. Mar Pet Geol 28(8):1444-1460. 382doi: 10.1016/j.marpetgeo.2011.04.003

3834. Vajdova V, Baud P, Wong T (2004) Permeability evolution during localized deformation in 384Bentheim sandstone. J Geophys Res 109:B10406. doi: 10.1029/2003JB002942

3855. Antonellini M, Aydin A (1994) Effect of faulting on fluid flow in porous sandstones; 386petrophysical properties. AAPG Bull 78:355-377.

3876. Torabi A, Fossen H, Alaei B (2008) Application of spatial correlation functions in permeability 388estimation of deformation bands in porous rocks. J Geophy Res 113:B08208. doi: 38910.1029/2007JB005455

3907. Aydin A, Berryman J (2010) Analysis of the growth of strike-slip faults using effective 391medium theory. J Struct Geol 32:1629-1642. doi: 10.1016/j.jsg.2009.11.007

3928. Cashman S, and Cashman K (2000) Cataclasis and deformation-band formation in 393unconsolidated marine terrace sand, Humboldt County, California. Geology 28(2):111-114. doi: 39410.1130/0091-7613(2000)28<111:CADFIU>2.0.CO;2

3959. Du Bernard X, Eichhubl P, Aydin A (2002) Dilation bands: A new form of localized failure in 396granular media. Geophys Res Letters 29(24):2176. doi: 10.1029/2002GL015966

39710. Sulem J, Ouffroukh H (2006) Shear banding in drained and undrained triaxial tests on a 398saturated sandstone: Porosity and permeability evolution. Int J Rock Mech Min Sci 43:292-310. 399doi: 10.1016/j.ijrmms.2005.07.001 
40011. Wong T, David C, Zhu W (1997) The transition from brittle faulting to cataclastic flow in 401porous sandstone: Mechanical deformation. J Geophys Res 102:3009-302. 402doi: 10.1029/96JB03281

40312. Bésuelle P (2001) Compacting and dilating shear bands in porous rocks: Theoretical and 404experimental conditions. J Geophys Res 106:13435-13442. doi: 10.1029/2001JB900011

40513. Baud P, Klein E, Wong T (2004) Compaction localization in porous sandstones: Spatial 406evolution of damage and acoustic emission activity. J Struct Geol 26:603-624. doi: 40710.1016/j.jsg.2003.09.002

40814. Fortin J, Stanchits S, Dresen G, Gue'guen Y (2006) Acoustic emission and velocities 409associated with the formation of compaction bands. J Geophys Res 111:B10203. doi: 41010.1029/2005JB003854

41115. Wong T, Baud P (2012) The brittle-ductile transition in porous rock: A review. J Struct Geol 41244:25-53. doi: 10.1016/j.jsg.2012.07.010

41316. Torabi A (2014) Cataclastic bands in immature and poorly lithified sandstone, examples 414from Corsica, France. Tectonophysiscs, http://dx.doi.org/10.1016/j.tecto.2014.05.014.

41517. Torabi A, Zarifi Z (2014) Energy release rate for propagating deformation bands and their 416hosted cracks. International Journal of Rock Mechanics and Mining Sciences 67, 184-190.

41718. Andò E, Hall SA, Viggiani G, Desrues J, Bésuelle P (2012a) Grain-scale experimental 418investigation of localised deformation in sand: a discrete particle tracking approach. Acta 419Geotechnica 7:1-13. doi: 10.1007/s11440-011-0151-6

42019. Andò E, Hall SA, Viggiani G, Desrues J, Bésuelle P (2012b) Experimental micromechanics: 421grain-scale observation of sand deformation. Géotechnique Letters 2:107-112. doi: 42210.1680/geolett.12.00027

42320. Andò E, Hall SA, Viggiani G, Desrues J (2013) Experimental micro-mechanics of granular 424media studied by x-ray tomography: recent results and challenges. Géotechnique Letters 3:142425146. doi: 10.1680/geolett.13.00036 
42621. Sibleco France (2011) Fiche Technique Type HN31. available at: 427http://www.sibelco.fr/item_img/medias/images/ft12_hn31.pdf

42822. Desrues J, Viggiani G (2004) Strain localization in sand: an overview of the experimental 429results obtained in Grenoble using stereophotogrammetry. Int J Numer Anal Meth Geomech 43028(4):279-322. doi: 10.1002/nag.338

43123. Colliat-Dangus JL, Desrues J, Foray P (1988) Triaxial testing of granular soi1 under elevated 432cell pressure. In: Donaghe RT, Chaney RC, and Silver ML (Eds) Advanced triaxial testing of 433soi1 and rock, ASTM STP 977, American Society for Testing and Materials, Philadelphia, pp $434290-310$

43524. Andò E (2013), PhD Thesis, Experimental investigation of micro-structural changes in 436deforming granular media using x-ray tomography, Université de Grenoble

43725. Kim HK, Santamarina J (2008) Sand-rubber mixtures (large rubber chips). Canadian 438Geotechnical Journal 45(10):1457-1466. doi: 10.1139/T08-070

43926. Hall SA, Bornert M, Desrues J, Pannier Y, Lenoir N, Viggiani G, Bésuelle P (2010) Discrete 440and continuum analysis of localised deformation in sand using X-ray $\mu \mathrm{CT}$ and volumetric digital 441image correlation. Géotechnique 60:315-322. doi: 10.1680/geot.2010.60.5.315

44227. Hall SA (2006) A methodology for 7D warping and deformation monitoring using time-lapse 443seismic data. Geophysics 71(4):O21-O31. doi: 10.1190/1.2212227

44428. Miura N, Yamanouchi T (1973) Compressibility and drained shear characteristics of a sand 445under high confining pressures. Technology reports of the Yamaguchi University 1(2):271 -290

44629. Zoback MD, Byerlee JD (1976) Effect of high-pressure deformation on permeability of 447Ottawa sand. AAPG Bulletin 60(9):1531-1542

44830. Lothe AE, Gabrielsen RH, Bjørnevoll HN, Larsen T (2002) An experimental study of the 449texture of deformation bands: effects on the porosity and permeability of sandstones. Petroleum 450Geoscience 8:195-207. doi: 10.1144/petgeo.8.3.195 


\section{Figures}
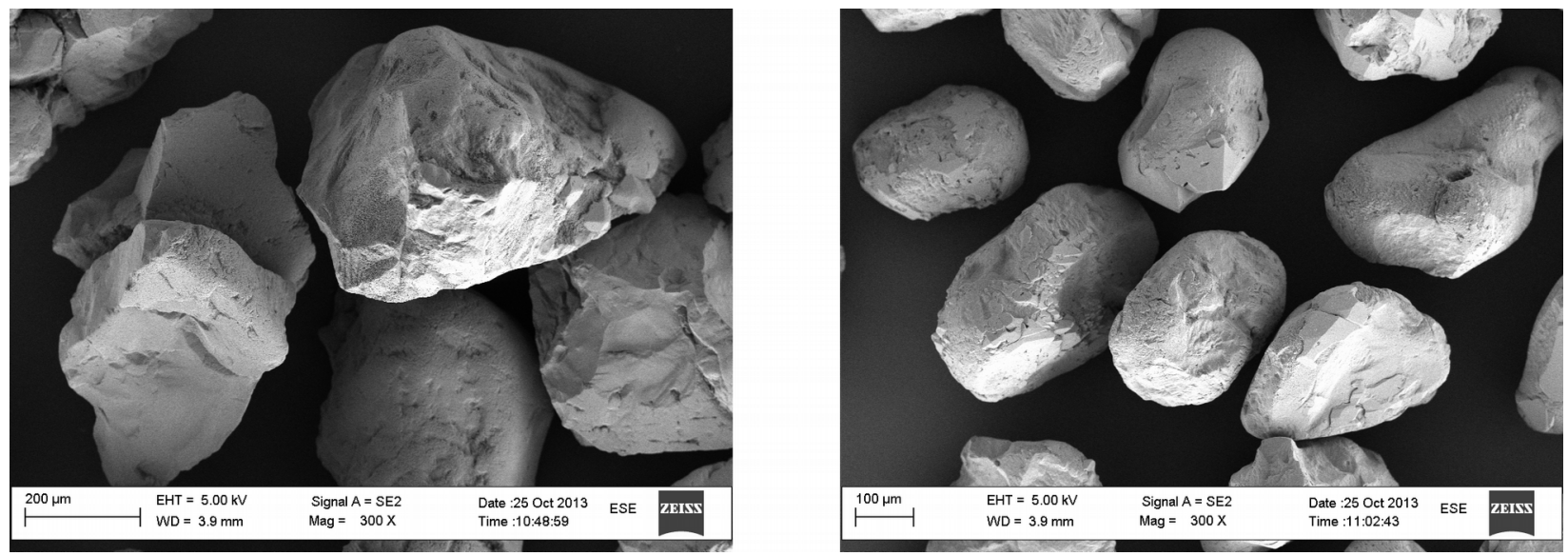

452Fig. 1 Scanning Electron Microscope (SEM) images of: left) angular Hostun sand grains, and 453right) rounded Ottawa sand grains

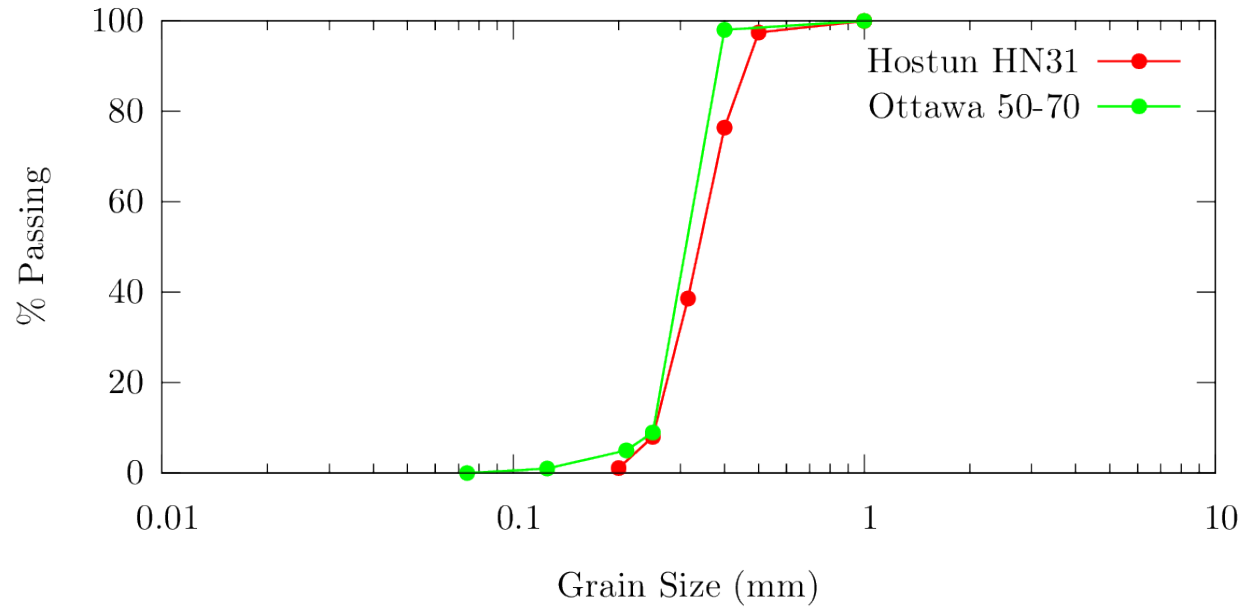

454Fig. 2 Grain size distribution curves for the two sands studied in this work. Data for Hostun sand 455comes from the manufacturer [21], and data for Ottawa sand from Kim and Santamarina [25] 


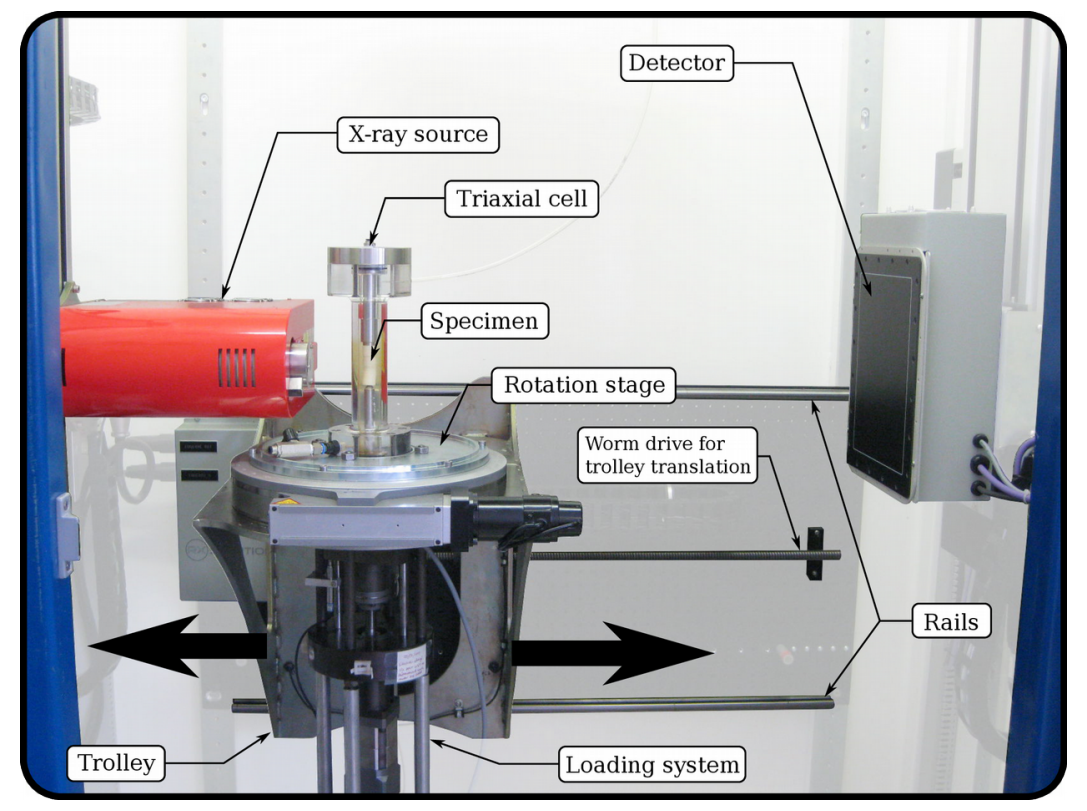

456Fig. 3 Labelled photograph of the Laboratoire 3SR x-ray scanner, with background faded out for 457clarity

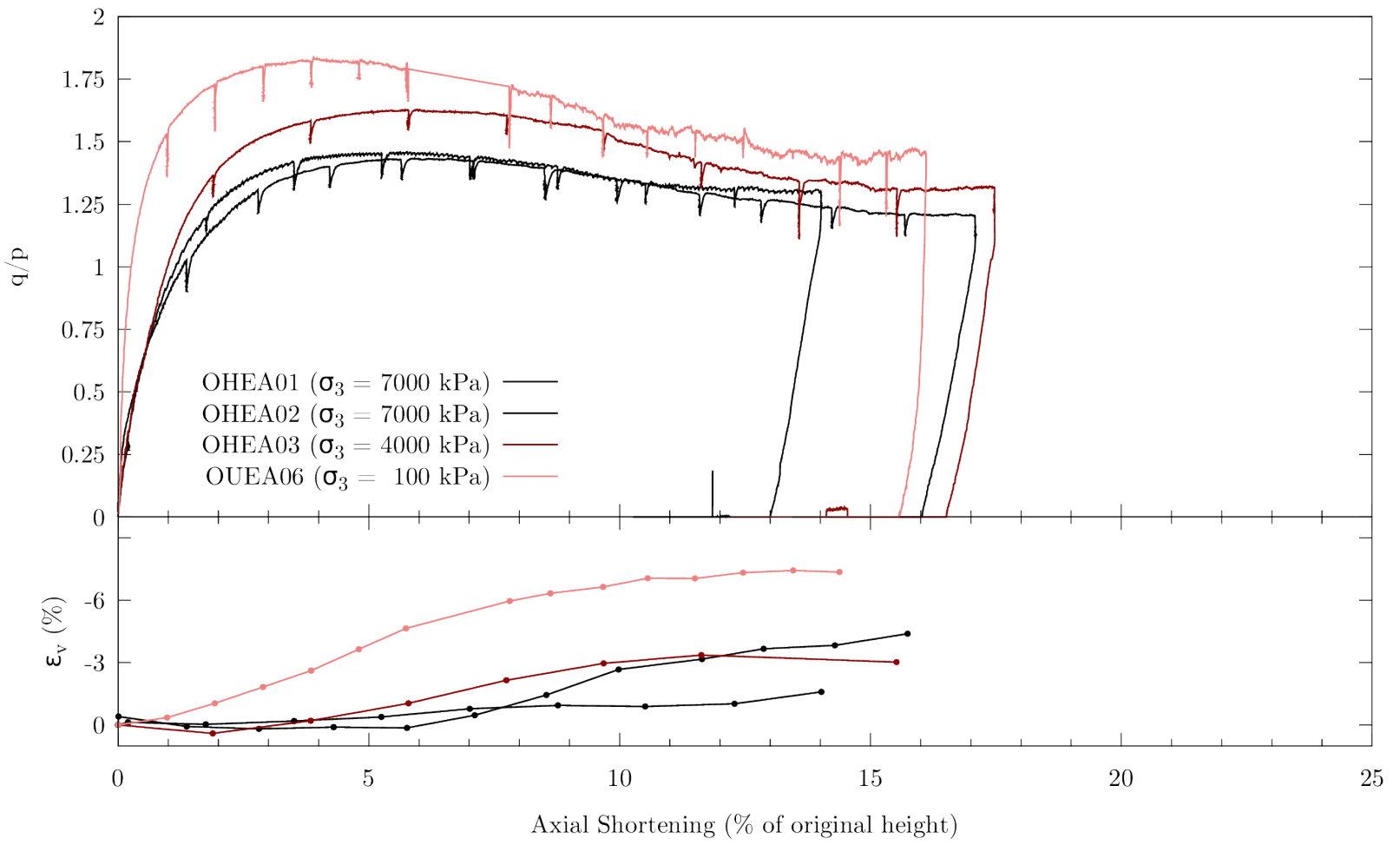

458Fig. 4 Deviatoric stress normalised by the mean stress (q/p) vs. axial shortening (top) and 459volumetric strain vs. axial shortening (bottom) for triaxial compressions tests on Ottawa sand 


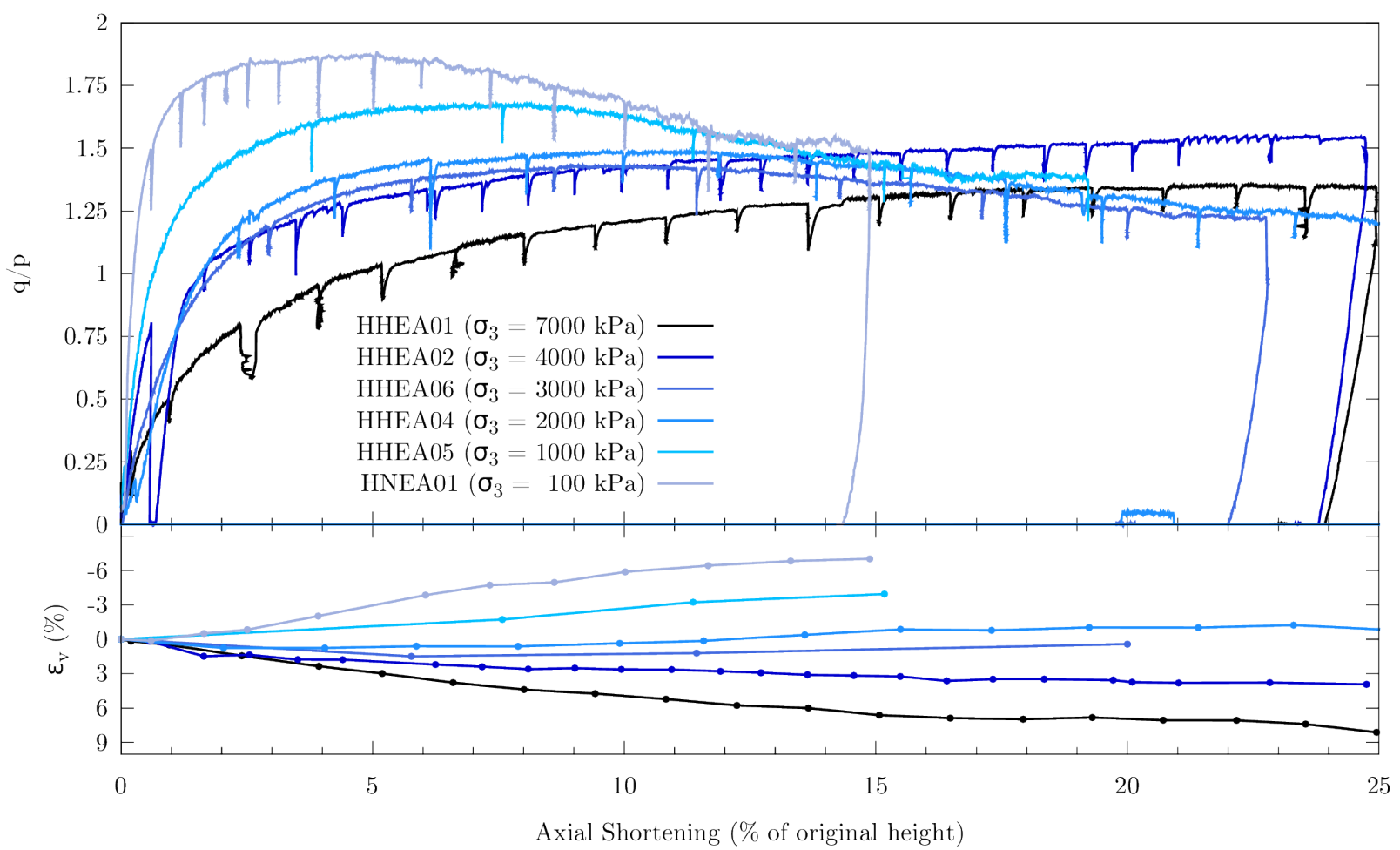

460Fig. 5 Deviatoric stress normalised by the mean stress (q/p) vs. axial shortening (top) and 461volumetric strain vs. axial shortening (bottom) for triaxial compressions tests on Hostun sand

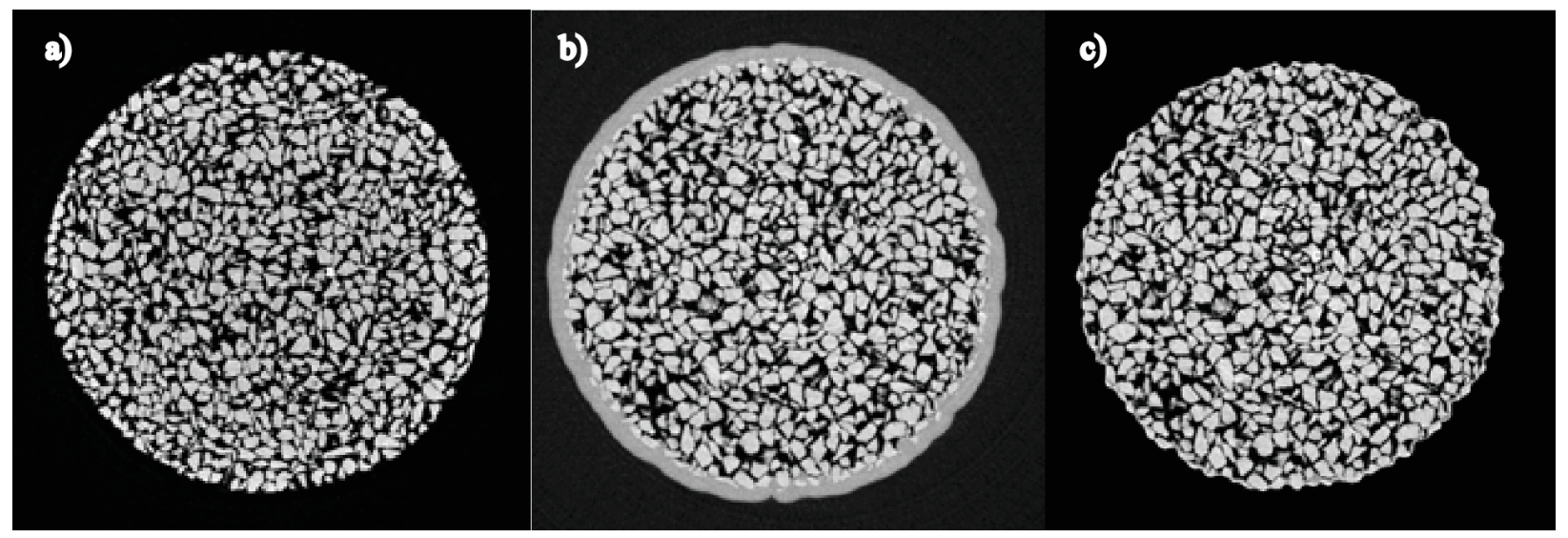

462Fig. 6 Horizontal slice of a specimen of Hostun sand a) under low confining pressure, b) and c) 463under high confining pressure but before and after membrane removal, respectively 
Original greyscale image HHEA01-03

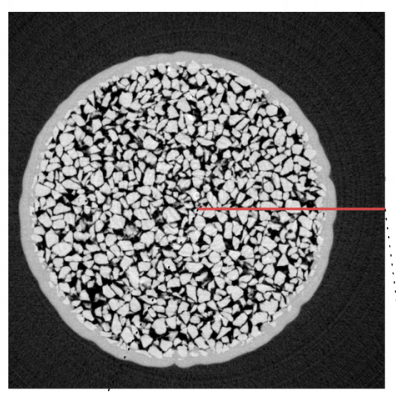

Final mask for this slice
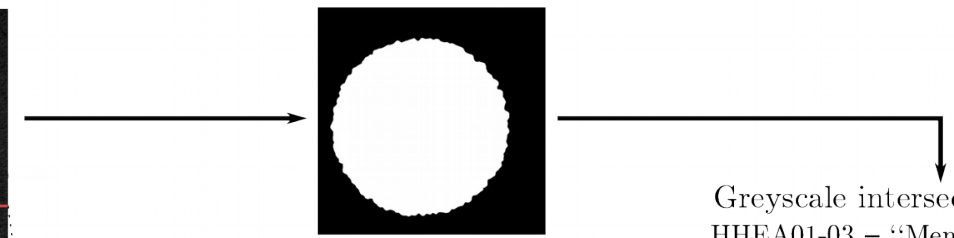

Greyscale intersected with mask HHEA01-03 - "Membrane Removed"

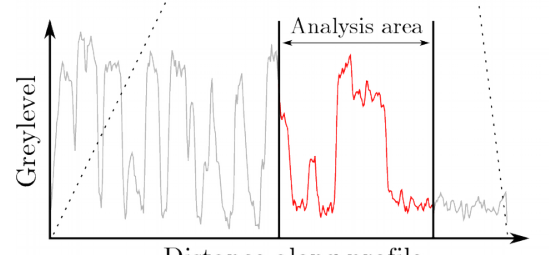
$\left.\begin{array}{l}\text { Smooth border } \\ \text { domain (in 3D) }\end{array}\right\}$ within restricted
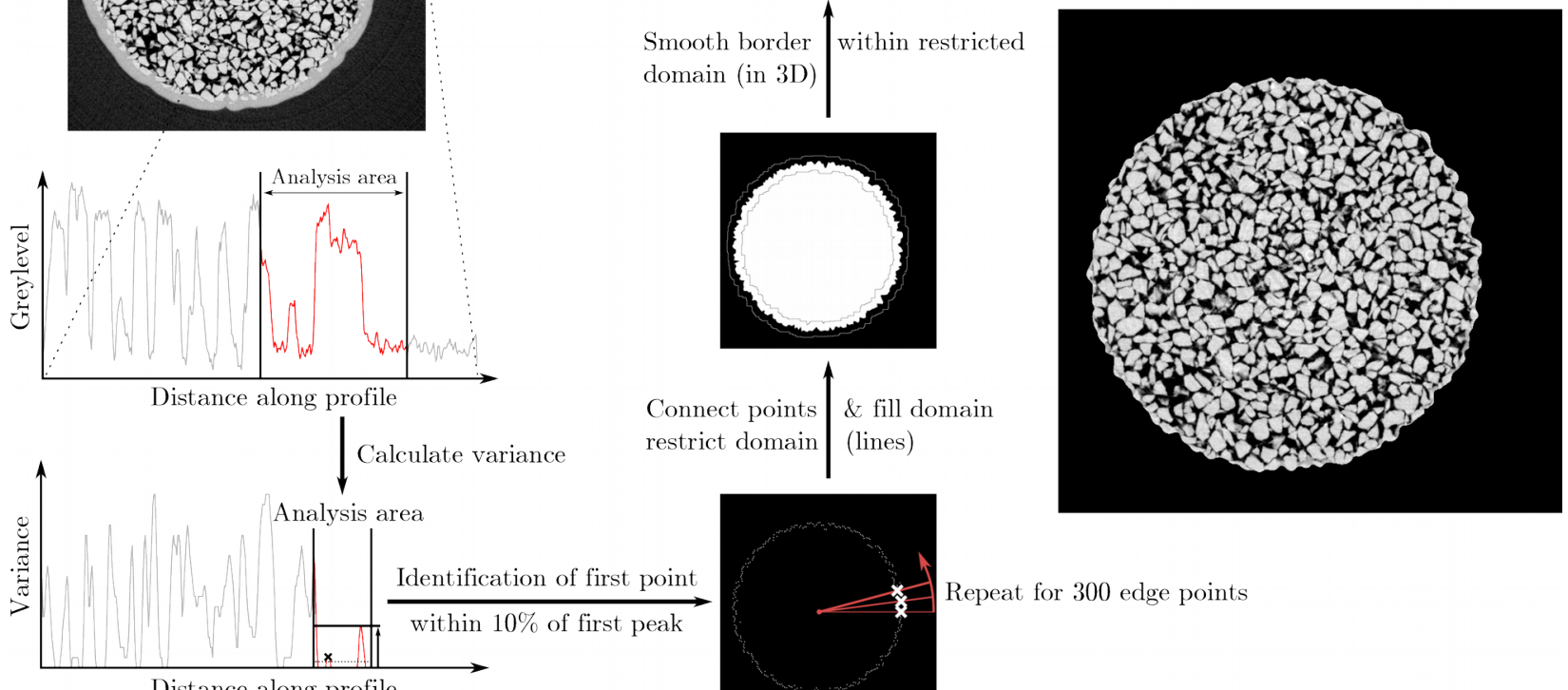
$\begin{array}{ll}\begin{array}{l}\text { Connect points } \\ \text { restrict domain }\end{array} & \begin{array}{l}\& \text { fill } \\ \text { (lines) }\end{array}\end{array}$

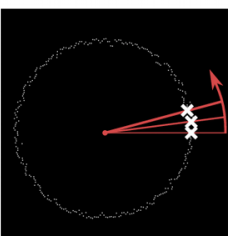

Repeat for 300 edge points

464Fig. 7 Illustration of the technique developed for the identification and removal of the membrane 465from the 3D images acquired with the high pressure cell setup
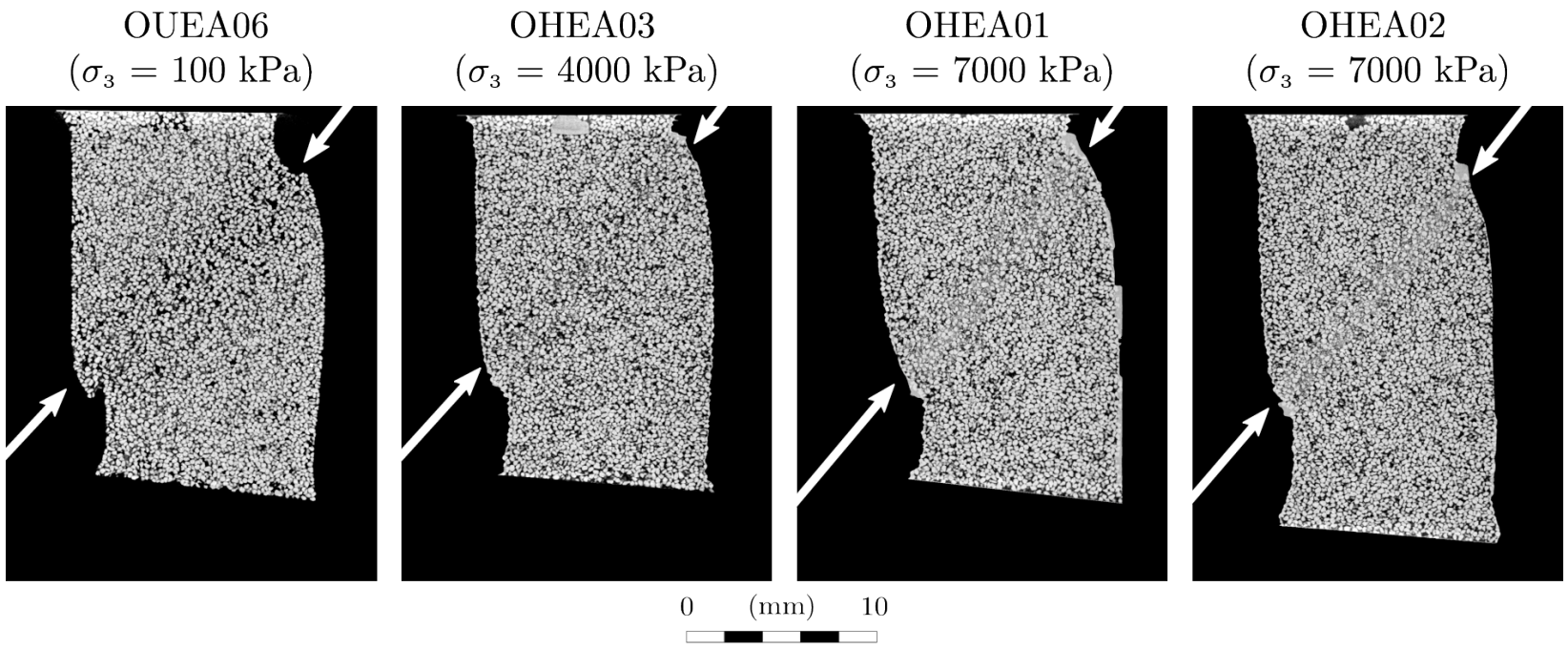

466Fig. 8 Vertical slices through the last image acquired in each test on Ottawa sand 
467

49 


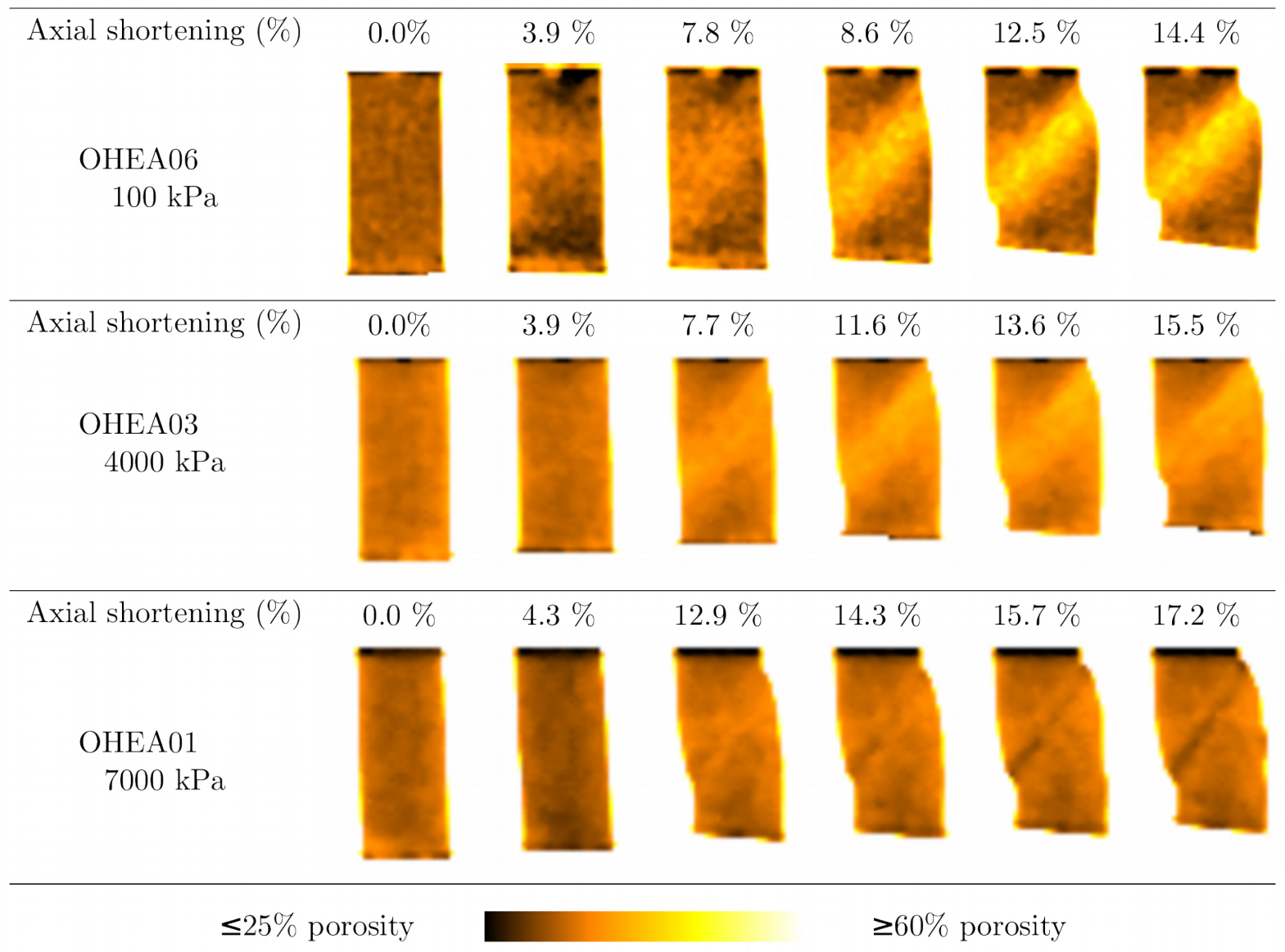

468Fig. 9 Porosity maps of some selected states of the specimens of Ottawa sand during shearing 


\begin{tabular}{|c|c|c|c|c|}
\hline & $\begin{array}{c}01-02 \\
0.0 \%-1.0 \%\end{array}$ & $\begin{array}{c}06-07 \\
4.8 \%-5.7 \%\end{array}$ & $\begin{array}{c}08-09 \\
7.8 \%-8.6 \%\end{array}$ & $\begin{array}{c}14-15 \\
13.5 \%-14.4 \%\end{array}$ \\
\hline \multirow{3}{*}{\multicolumn{5}{|c|}{$\begin{array}{l}\text { OUEA06 } \\
100 \mathrm{kPa} \\
\text { Volumetric Strain }\end{array}$}} \\
\hline & & & & \\
\hline & & & & \\
\hline \multicolumn{5}{|l|}{ Shear Strain } \\
\hline & $\begin{array}{c}01-02 \\
0.0 \%-1.9 \%\end{array}$ & $\begin{array}{c}03-04 \\
3.8 \%-5.8 \%\end{array}$ & $\begin{array}{c}05-06 \\
7.7 \%-9.7 \%\end{array}$ & $\begin{array}{c}08-09 \\
13.6 \%-15.5 \%\end{array}$ \\
\hline \multicolumn{5}{|l|}{ OHEA03 } \\
\hline \multicolumn{5}{|c|}{$4000 \mathrm{kPa}$} \\
\hline \multicolumn{5}{|l|}{ Shear Strain } \\
\hline & $\begin{array}{c}03-05 \\
0.0 \%-1.4 \%\end{array}$ & $\begin{array}{c}07-08 \\
4.3 \%-5.8 \%\end{array}$ & $\begin{array}{c}10-12 \\
8.5 \%-11.6 \%\end{array}$ & $\begin{array}{c}15-16 \\
15.7 \%-17.2 \%\end{array}$ \\
\hline \multicolumn{5}{|l|}{ OHEA01 } \\
\hline \multicolumn{5}{|c|}{$7000 \mathrm{kPa}$} \\
\hline \multicolumn{5}{|l|}{ Shear Strain } \\
\hline & & & $\begin{array}{l}\text { Volumet } \\
\text { (Compact }\end{array}$ & \\
\hline $0 \%$ & & & & $\geq 5 \%$ \\
\hline
\end{tabular}

469Fig. 10 DIC Results for OUEA06, OHEA03 and OHEA01 
HNEA01

$\left(\sigma_{3}=100 \mathrm{kPa}\right)$

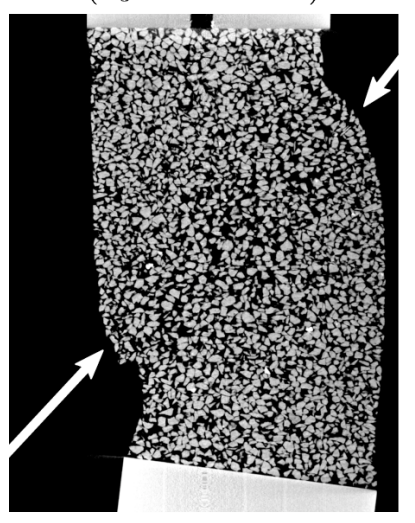

HHEA06

$\left(\sigma_{3}=3000 \mathrm{kPa}\right)$

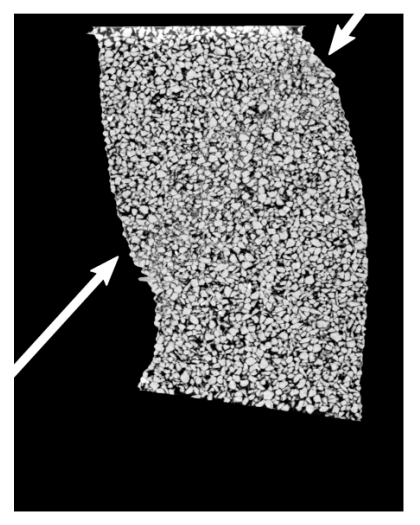

HHEA05

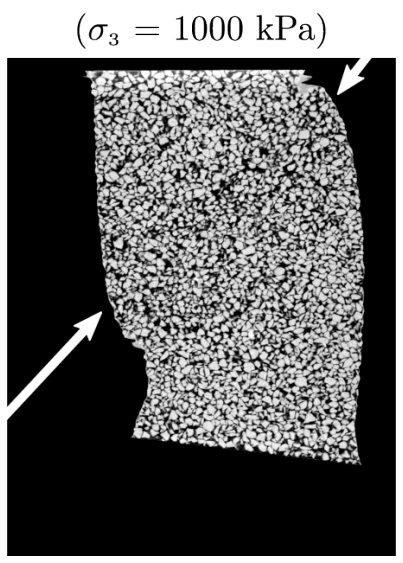

HHEA02

$\left(\sigma_{3}=4000 \mathrm{kPa}\right)$

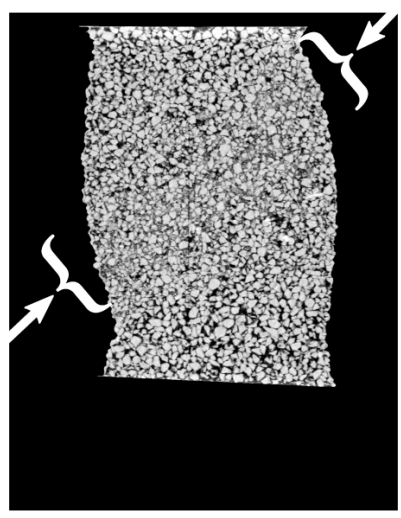

\begin{tabular}{lll}
$0 \quad(\mathrm{~mm})$ & 10 \\
\hline
\end{tabular}
HHEA04

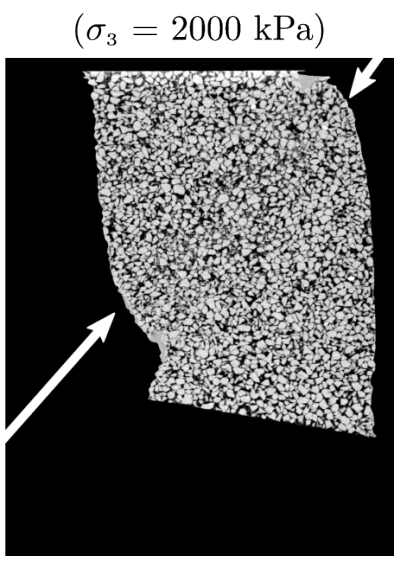

HHEA01

$\left(\sigma_{3}=7000 \mathrm{kPa}\right)$

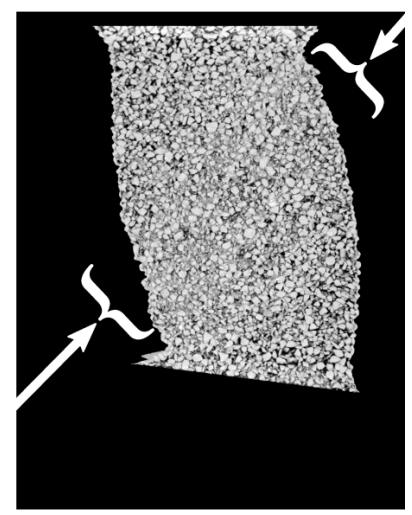

470Fig. 11 Vertical slices through the last image acquired in each test on Hostun sand 


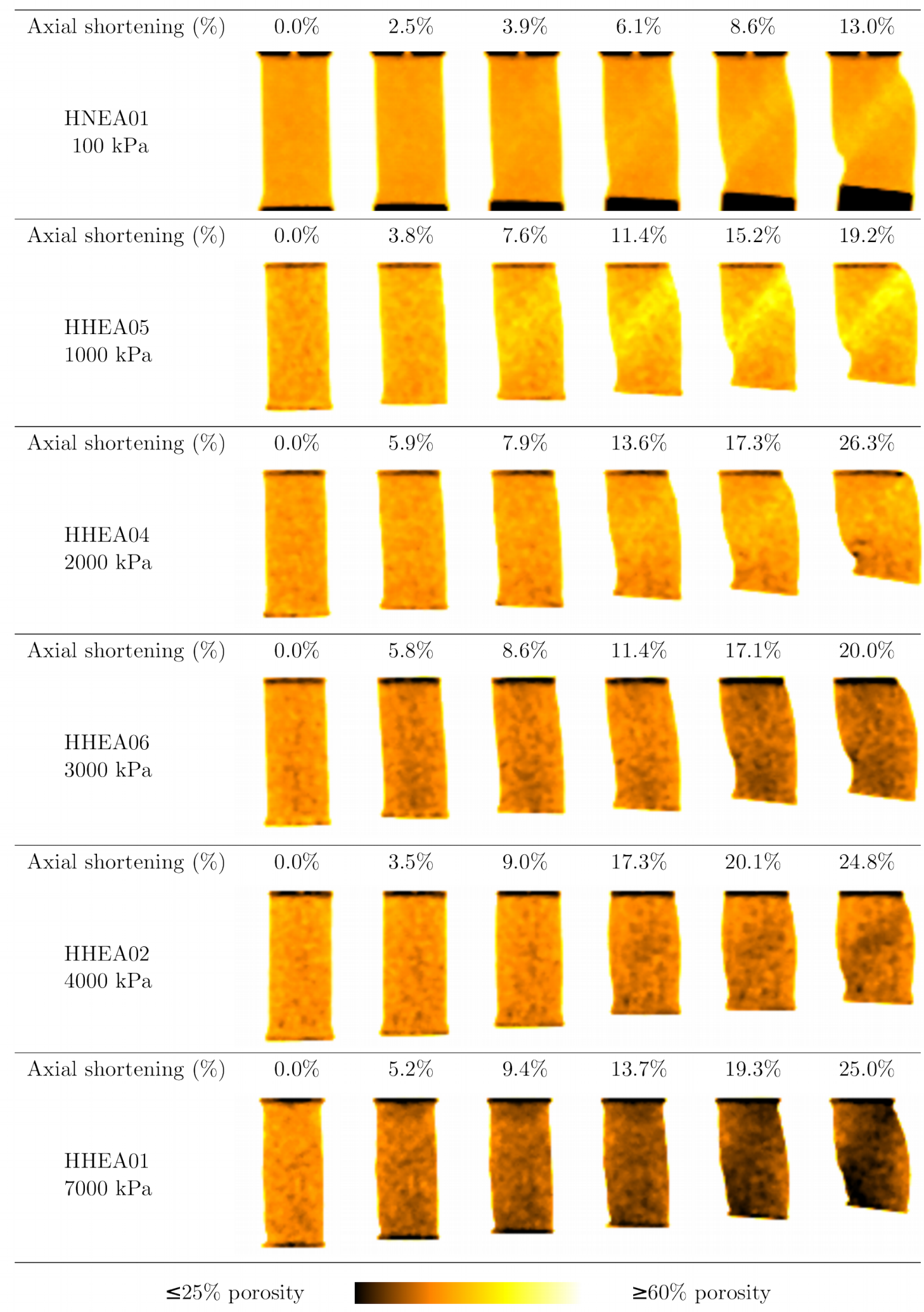

471Fig. 12 Porosity maps of some selected states of the specimens of Hostun sand during shearing 


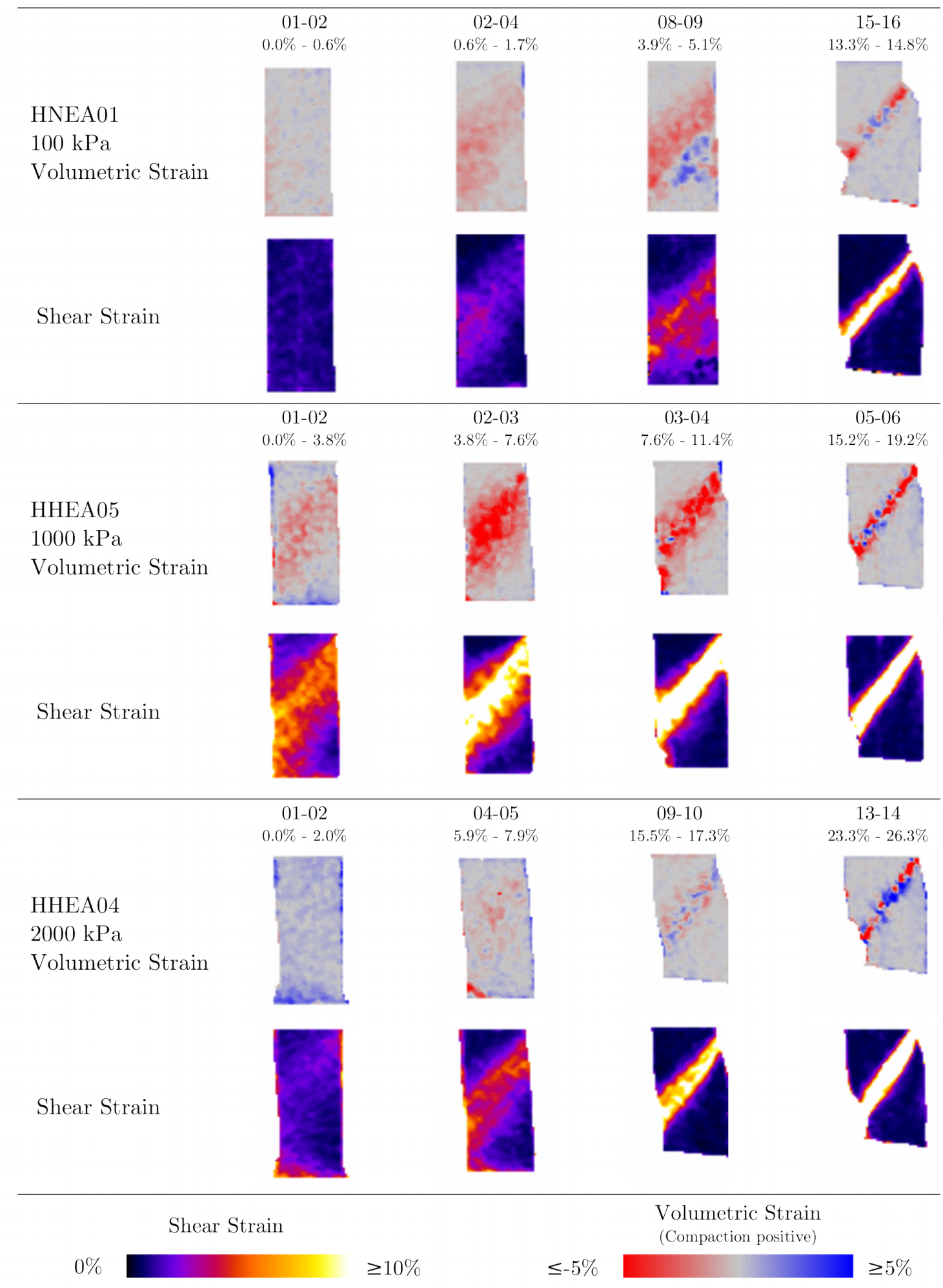

472Fig. 13 DIC Results for tests HNEA01, HHEA05 and HHEA04 


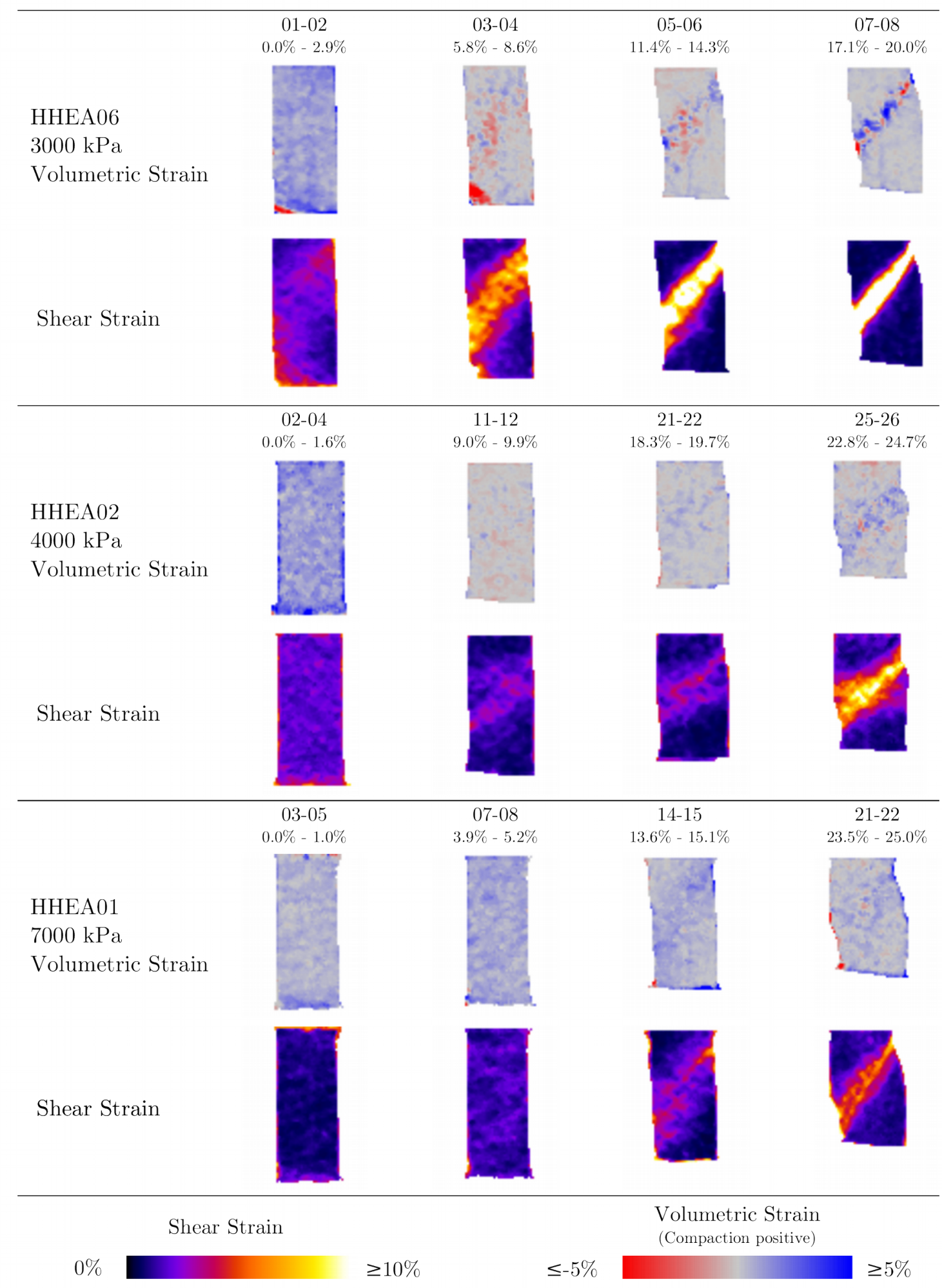

473Fig. 14 DIC Results for tests HHEA06, HHEA02 and HHEA01 

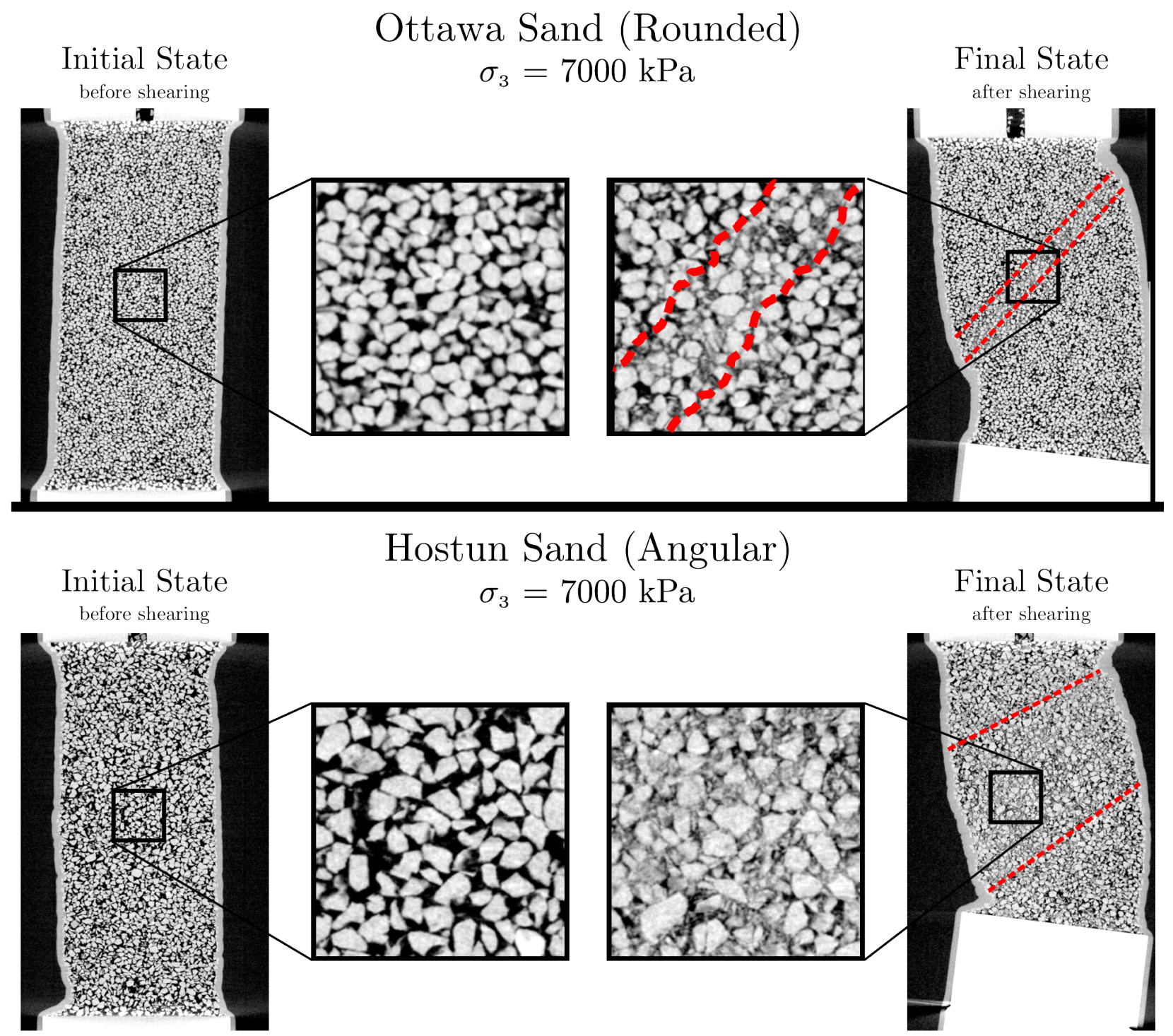

474Fig. 15 Vertical sections of Hostun and Ottawa sands (under $7000 \mathrm{kPa}$ confinement) with 475highlighted zones of intense grain crushing. 